\title{
Sistem Pendukung Keputusan Online untuk Menentukan Kelayakan Tenaga Kerja Indonesia (TKI) Menggunakan Metode Simple Additive Weighting (SAW) dan Weighted Product (WP)
}

\author{
The Online Decision Support System to Determine the Eligibility of \\ Indonesian Workers (TKI) Using the Simple Additive Weighting (SAW) and \\ Weighted Product (WP) Methods
}

\author{
Dimas Anugerah Adibrata ${ }^{1}$, Hindayati Mustafidah ${ }^{2}$ \\ ${ }^{1,2}$ Teknik Informatika - Universitas Muhammadiyah Purwokerto \\ ${ }^{1}$ corr-author: h.mustafidah@ump.ac.id
}

\begin{abstract}
ABSTRAK
PPTKIS CIKAL DIAN ASTUTI adalah instansi penyalur Tenaga Kerja Indonesia (TKI) yang melaksanakan pendaftaran, pelatihan dan pemberangkatan tenaga kerja ke luar negeri. Untuk membantu memperlancar dan mempercepat penentuan TKI yang layak dikirim, diperlukan sebuah sistem yang selama ini masih menggunakan cara manual. Sistem Pendukung Keputusan (SPK) merupakan sebuah sistem yang dapat digunakan untuk membantu dalam memutuskan suatu masalah. Oleh karena itu penelitian ini mengembangkan SPK untuk membantu memberikan rekomendasi dalam menentukan kelayakan Tenaga Kerja Indonesia (TKI) di PPTKIS CIKAL DIAN ASTUTI untuk diberangkatkan ke luar negeri sesuai kriteria yang sudah ditetapkan. Metode yang digunakan adalah Simple Additive Weighting (SAW) dan Weighted Product (WP). Kriteria yang digunakan berupa pengalaman kerja, kesehatan, usia, dan pendidikan terakhir. Berdasarkan pengujian dengan berbagai kasus yang berbeda terhadap kedua metode Simple Additive Weighting (SAW) dan Weighted Product (WP) diperoleh hasil rekomendasi yang sama sehingga kedua metode tersebut dapat diterapkan dalam pengambilan keputusan pada PPTKIS CIKAL DIAN ASTUTI.
\end{abstract}

Kata-kata kunci: Sistem Pendukung Keputusan, Simple Additive Weighting, Weighted Product, Tenaga Kerja Indonesia

\begin{abstract}
PPTKIS CIKAL DIAN ASTUTI is an agency that supplies Indonesian Workers (TKI), which carries out registration, training, and dispatch of workers abroad. To help expedite and accelerate the determination of TKI that is fit to be taken off, we need a system that still uses the manual method. A Decision Support System (DSS) is a system that can be used to assist in deciding on a problem. Therefore, this study develops SPK to help provide recommendations in determining the eligibility of Indonesian Workers (TKI) in PPTKIS CIKAL DIAN ASTUTI to be dispatched abroad according to predetermined criteria. The method used is Simple Additive Weighting (SAW) and Weighted Product (WP). The criteria used are work experience, health, age, and latest education. Based on testing with different cases on the two methods of Simple Additive Weighting (SAW) and Weighted Product (WP), the same recommendation results were obtained to apply both methods in decision-making at CIKAL DIAN ASTUTI PPTKIS.
\end{abstract}




\section{Keywords: Decision support system, Simple Additive Weighting, Weighted Product, Indonesian Workers}

\section{PENDAHULUAN}

Tenaga Kerja Indonesia (TKI) merupakan salah satu penyumbang devisa bagi negara Indonesia. Setiap tahunnya orang-orang yang diberangkatkan ke luar negeri berjumlah ribuan. Menurut data yang tercatat pada BNP2TKI pada tahun 2017 khususnya di wilayah Cilacap ada sekitar 5.448 orang yang diberangkatkan. PPTKIS CIKAL DIAN ASTUTI merupakan suatu perusahaan yang bergerak pada jasa penyaluran Tenaga Kerja Indonesia (TKI) ke luar negeri. Selama ini dalam pengambilan keputusan penentuan kelayakan Tenaga Kerja Indonesia (TKI) yang akan diberangkatkan ke luar negeri pada tahap seleksi calon TKI di PPTKIS CIKAL DIAN ASTUTI dilakukan secara manual, yaitu dengan penyeleksian kelengkapan syarat dokumen. Meskipun prosedur yang berjalan sampai saat ini, secara umum telah dapat menentukan kelayakan calon TKI, namun prosedur tersebut dirasa masih perlu diadakan peningkatan dalam segi kualitas dalam pengambilan keputusan dengan didukung oleh sistem pendukung keputusan.

Berdasarkan uraian yang telah dipaparkan, dibutuhkan aplikasi yang dapat digunakan untuk membantu PPTKIS CIKAL DIAN ASTUTI dalam pengambilan keputusan penentuan kelayakan Tenaga Kerja Indonesia (TKI) ke luar negeri. Oleh karena itu, penelitian ini mengembangkan sistem pendukung keputusan (SPK) sebagai alat bantu bagi manajemen dalam mengambil keputusan, karena SPK juga digunakan oleh Ariani, et.al. (2013) dalam penelitian untuk memecahkan masalah serupa. Metode yang digunakan dalam penelitian ini adalah metode Simple Additive Weighting (SAW) dan Weighted Product (WP). Metode Simple Additive Weighting (SAW) sering juga dikenal dengan istilah metode penjumlahan berbobot. Konsep dasar metode Simple Additive Weighting (SAW) adalah mencari penjumlahan terbobot dari rating kinerja pada setiap alternatif pada semua atribut. Metode Simple Additive Weighting (SAW) disarankan untuk menyelesaikan masalah penyeleksian dalam sistem pengambilan keputusan yang memiliki banyak atribut. Metode Simple Additive Weighting (SAW) membutuhkan proses normalisasi matriks keputusan $(X)$ ke suatu skala yang didapat dibandingkan dengan semua rating alternatif yang ada (Nofriansyah, 2014). Sementara itu, Metode Weighted Product (WP) merupakan salah satu metode sederhana dengan perkalian untuk menghubungkan rating atribut, dimana setiap rating setiap atribut harus dipangkatkan dengan bobot atribut yang bersangkutan (Nofriansyah, 2014).

Beberapa penelitian terkait kedua metode SAW dan WP yang telah dilakukan adalah Anto, et.al. (2015) melakukan pengembangan sistem pendukung keputusan penilaian kinerja karyawan Universitas Muhammadiyah Purwokerto menggunakan metode Simple Additive Weighting (SAW). Kriteria yang digunakan adalah kehadiran, pendidikan, pengembangan diri, dan penunjang. Hasil dari penelitian ini memberikan rekomendasi kinerja karyawan dengan nilai terbaik sesuai kriteria yang telah ditentukan. Penelitian lain terkait metode Simple Additive Weighting (SAW) oleh Adlhiyah \& Mustafidah (2016) yang melakukan penelitian untuk menentukan pemilihan lensa kontak (softlens) menggunakan metode Simple Additive Weighting (SAW). Kriteria yang digunakan adalah harga, masa 
pemakaian, kandungan air, warna, dan ukuran diameter. Sementara itu, metode Weighted Product (WP) digunakan oleh Mustafidah \& Hadyan (2017) dalam pengembangan sistem pendukung keputusan untuk menentukan mahasiswa berprestasi. Kriteria yang digunakan dalam penelitian ini adalah IPK, karya tulis, prestasi, dan kemampuan bahasa inggris. Penelitian lainnya terkait metode Weighted Product (WP) dilakukan oleh Yoni \& Mustafidah (2016) untuk menentukan mahasiswa lulusan terbaik di Fakultas Teknik Universitas Muhammadiyah Purwokerto. Kriteria yang digunakan dalam penelitian ini adalah IPK, masa studi, nilai $\mathrm{C}$ maksimal 1 , dan tidak ada nilai D.

Batasan masalah dalam penelitian ini adalah sistem ini hanya membahas tentang penentuan kelayakan Tenaga Kerja Indonesia (TKI) ke luar negeri yang telah lulus psikotes serta uji kompetensi dengan kriteria pengalaman kerja, kesehatan, usia, dan pendidikan terakhir. Manfaat yang diharapkan dari penelitian ini adalah membantu PPTKIS CIKAL DIAN ASTUTI dalam penentuan kelayakan Tenaga Kerja Indonesia (TKI) ke luar negeri sesuai dengan kriteria yang ditetapkan.

\section{METODE PENELITIAN}

Jenis penelitian ini adalah penelitian rekayasa atau pengembangan yaitu pengembangan aplikasi sistem pendukung keputusan untuk menentukan kelayakan Tenaga Kerja Indonesia (TKI) ke luar negeri menggunakan metode Simple Additive Weighting (SAW) dan Weighted Product (WP). Variabel penelitian berupa kriteria pengalaman kerja, kesehatan, usia, dan pendidikan terakhir,.

Pengumpulan data dan informasi dilakukan menggunakan 2 cara yaitu wawancara dan dokumentasi. Wawancara dilakukan dengan bertanya secara langsung kepada pihak PPTKIS CIKAL DIAN ASTUTI mengenai kriteria kelayakan Tenaga Kerja Indonesia (TKI) dan pembobotannya. Dokumentasi dilakukan dengan cara mengambil data yang sudah ada untuk mendukung kelengkapan penelitian.

Model pengambilan keputusan yang dibangun digambarkan menggunakan flowchart seperti pada Gambar 1.

Seperti telah disampaikan pada bagian sebelumnya, bahwa penelitian ini menggunakan dua metode yaitu SAW dan WP. Langkah-langkah penyelesaian menggunakan kedua metode ini dijelaskan seperti berikut.

\section{Metode SAW}

Langkah yang dilakukan dalam metode SAW adalah sebagai berikut:

- Menentukan alternatif, yaitu $\mathrm{A}_{\mathrm{i}}$.

- Menentukan kriteria yang dijadikan acuan dalam pengambilan keputusan $\left(\mathrm{C}_{\mathrm{j}}\right)$.

- Memberikan nilai rating kecocokan setiap alternatif pada setiap kriteria.

- menentukan bobot preferensi atau tingkat kepentingan (W) setiap kriteria seperti pada persamaan 1 .

$$
\mathrm{W}=\left[\mathrm{W}_{1}, \mathrm{~W}_{2}, \ldots, \mathrm{W}_{\mathrm{j}}\right]
$$

- Menentukan tabel rating kecocokan dari setiap alternatif pada setiap kriteria.

- Membuat matrik keputusan (X) yang dibentuk dari tabel rating kecocokan dari setiap alternatif pada setiap kriteria, seperti pada persamaan 2 . 


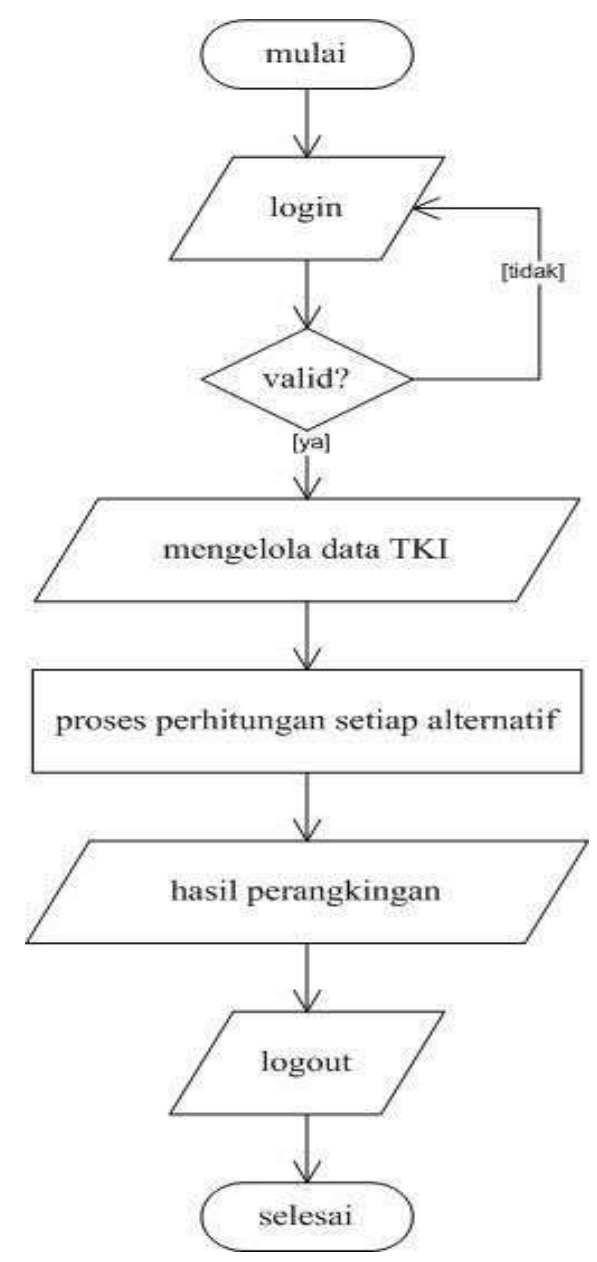

Gambar 1. Flowchart sistem pendukung keputusan penentuan kelayakan TKI

Keterangan :

$$
X=\left[\begin{array}{cccc}
X_{11} & X_{12} & \cdots & X_{1 j} \\
X_{21} & X_{22} & \cdots & X_{2 j} \\
\vdots & \vdots & & \vdots \\
X_{i 1} & X_{i 2} & \cdots & X_{i j}
\end{array}\right]
$$

$X=$ nilai dari setiap alternatif

$i=$ alternatif

$j=$ kriteria

- Melakukan normalisasi matrik keputusan dengan cara menghitung nilai dari rating setiap kriteria ternormalisasi $\left(\mathrm{r}_{\mathrm{ij}}\right)$ dari alternatif $\mathrm{A}_{\mathrm{i}}$ pada kritera $\mathrm{C}_{\mathrm{j}}$ seperti pada persamaan 3 .

$$
r_{i j}=\left\{\begin{array}{l}
\frac{x_{i j}}{\operatorname{Max}\left(x_{i j}\right)} ; j i k a j \text { adalah atribut keuntungan }(\text { benefit) } \\
\frac{\operatorname{Min}\left(x_{i j}\right)}{x_{i j}} ; \quad \text { jika } j \text { adalah atribut biaya }(\text { cost })
\end{array}\right.
$$

Keterangan :

$r_{i j}=$ Nilai rating ternormalisasi

$x_{i j}=$ Nilai atribut yang dimiliki setiap kriteria 
$\operatorname{Max}\left(x_{i j}\right)=$ Nilai terbesar dari setiap kriteria

$\operatorname{Min}\left(x_{i j}\right)=$ Nilai terkecil dari setiap kriteria

Benefit $=$ Jika nilai terbesar adalah nilai terbaik

Cost $=$ Jika nilai terkecil adalah nilai terbaik

- Hasil dari nilai rating kinerja ternormalisasi $\left(x_{i j}\right)$ membentuk matrik ternormalisasi (R) seperti persamaan 4 berikut :

$$
R=\left[\begin{array}{cccc}
r_{11} & r_{12} & \cdots & r_{1 j} \\
r_{21} & r_{22} & \cdots & r_{2 j} \\
\vdots & \vdots & & \vdots \\
r_{i 1} & r_{i 2} & \cdots & r_{i j}
\end{array}\right]
$$

- Hasil akhir nilai preferensi $\left(\mathrm{V}_{\mathrm{i}}\right)$ diperoleh dari penjumlahan dari perkalian elemen baris matrik ternormalisasi (R) dengan bobot preferensi (W) yang bersesuaian elemen kolom matriks (W) seperti persamaan 5 berikut :

$$
V_{i}=\sum_{j=1}^{n} \mathrm{~W}_{j} r_{i j}
$$

Keterangan :

$V_{i}=$ Nilai akhir dari alternatif

$W_{i}=$ Bobot yang telah ditentukan

$r_{i j}=$ Normalisasi matriks

Nilai akhir alternative $V_{i}$ yang lebih besar yaitu alternatif yang terpilih.

\section{Metode WP}

Langkah-langkah penyelesaian menggunakan metode WP adalah sebagai berikut:

- Preferensi untuk alternatif $A_{i}$ diberikan oleh persamaan 6.

$$
S_{i}=\prod_{j=1}^{n} X_{i j}{ }^{w_{j}}
$$

Keterangan :

$S_{i}$ : Preferensi alternatif dianalogikan sebagai vektor $S$

$X_{i j}$ : Nilai variabel dari alternatif pada setiap atribut

$W_{i}$ : Nilai bobot kriteria

$n$ : Banyaknya kriteria

$i$ : Nilai alternatif

j : Nilai kriteria

- Dengan $\mathrm{I}=1,2, \ldots, \mathrm{m}$; dimana $\sum W_{j}=1 . W_{j}$ adalah pangkat bernilai positif untuk atribut keuntungan, dan bernilai negatif untuk atribut biaya oleh persamaan 7 .

$$
W_{j}=\frac{W_{j}}{\sum W_{j}}
$$

- Preferensi relatif dari setiap alternatif diberikan oleh persamaan 8.

Keterangan :

$$
V_{i}=\frac{\prod_{j=1}^{n}\left(x_{i j}\right)^{w_{j}}}{\prod_{j=1}^{n}\left(x_{j} *\right)^{W_{j}}}
$$

$V_{i}$ : Preferensi relatif dari setiap alternatif dianalogikan sebagai vektor $\mathrm{V}$

$X_{i j}$ : Nilai variabel dari alternatif pada setiap atribut

$W_{f}$ : Nilai bobot kriteria

$n$ : Banyaknya kriteria 
$i \quad$ : Nilai alternatif

$j \quad$ :Nilai kriteria

* : Banyaknya kriteria yang telah dinilai pada vektor $\mathrm{S}$

\section{HASIL DAN PEMBAHASAN}

\section{Penilaian Kriteria}

a. Pengalaman Kerja

Pengalaman kerja dapat dinilai dari lamanya TKI pernah bekerja di luar negeri. Tabel pengalaman kerja dapat dilihat pada Tabel 1 .

Tabel 1. Pengalaman Kerja

\begin{tabular}{ccc}
\hline No & Pengalaman Kerja & Nilai Crisp \\
\hline 1. & $<1$ Tahun & 1 \\
2. & 1 Tahun -3 Tahun & 2 \\
3. & 4 Tahun -6 Tahun & 3 \\
4. & 7 Tahun -9 Tahun & 4 \\
5. & Lebih dari 10 Tahun & 5 \\
\hline
\end{tabular}

b. Kesehatan

Kesehatan dapat dinilai dari hasil tes Kesehatan TKI sebagaimana pada Tabel 2.

Tabel 2. Kesehatan

\begin{tabular}{clc}
\hline No & \multicolumn{1}{c}{ Kesehatan } & Nilai Crisp \\
\hline 1. & Riwayat penyakit Kronis & 1 \\
2. & Riwayat penyakit sehari-hari / Biasa & 2 \\
3. & Sehat & 3 \\
\hline
\end{tabular}

c. Usia

Usia dapat dinilai dari usia TKI yang mendaftar (Tabel 3).

Tabel 3. Usia

\begin{tabular}{ccc}
\hline No & Usia & Nilai Crisp \\
\hline 1. & Lebih dari 30 Tahun & 1 \\
2. & 27 Tahun - 30 Tahun & 2 \\
3. & 24 Tahun -26 Tahun & 3 \\
4. & 21 Tahun -23 Tahun & 4 \\
5. & 18 Tahun -20 Tahun & 5 \\
\hline
\end{tabular}

\section{d. Pendidikan Terakhir}

Pendidikan terakhir dapat dinilai dari pendidikan formal apa yang terakhir dimiliki oleh TKI (Tabel 4). 
Tabel 4. Pendidikan Terakhir

\begin{tabular}{ccc}
\hline No & Pendidikan Terakhir & Nilai Crisp \\
\hline 1. & SD & 1 \\
2. & SMP & 2 \\
3. & SMA & 3 \\
4. & Diploma I - Diploma III & 4 \\
5. & Diploma IV - Sarjana & 5 \\
\hline
\end{tabular}

\section{Implementasi Sistem}

\section{a. Halaman Home}

Halaman home adalah halaman ketika pertama kali memulai sistem. Pada halaman ini terdapat halaman untuk karyawan (pertugas yang diberi tanggungjawab dari PT) melakukan login. Halaman home terdapat pada Gambar 3.

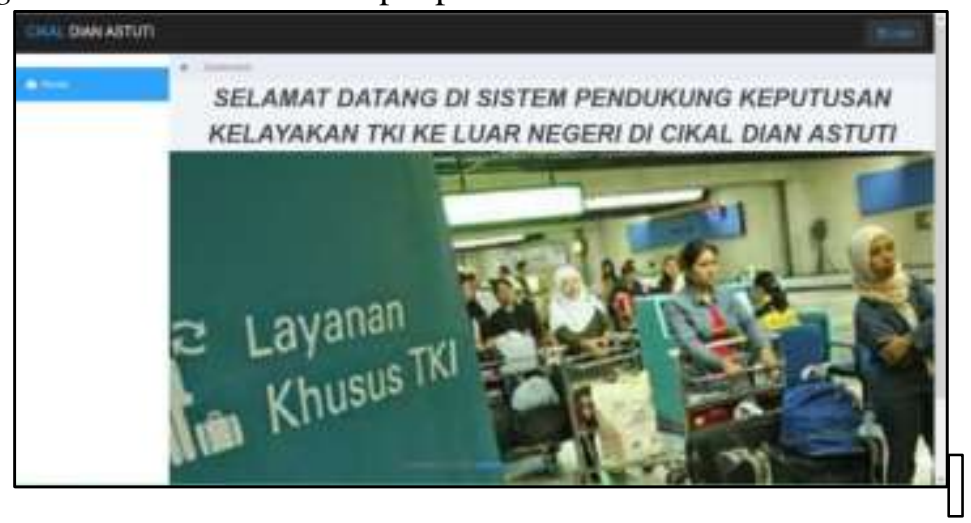

Gambar 3. Halaman Home A

\section{b. Halaman Login}

Halaman login adalah halaman yang digunakan sebelum karyawan dapat mengakses data TKI dan perangkingan. Untuk login karyawan harus mengakses menggunakan username dan password sehingga dapat masuk ke halaman data TKI dan perangkingan. Halaman login ditunjukkan pada Gambar 4.

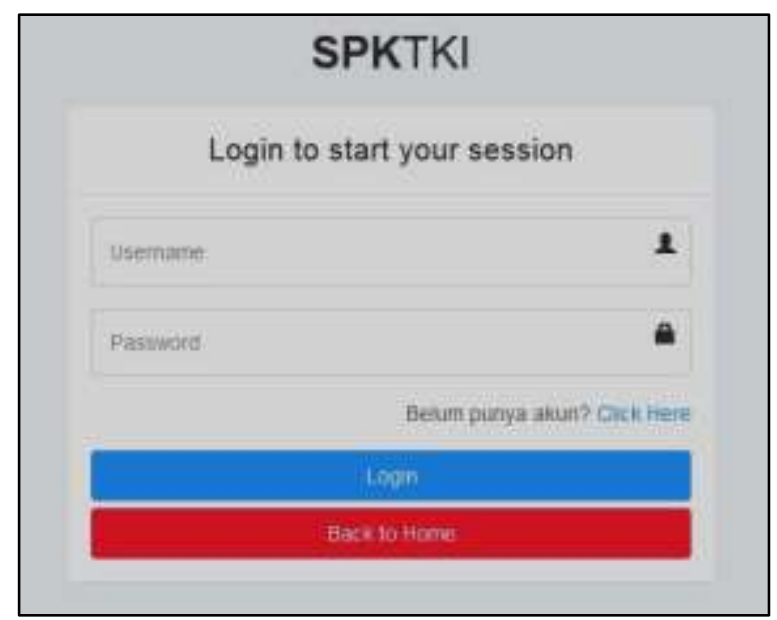

Gambar 4. Halaman login 


\section{c. Halaman Data TKI}

Halaman data TKI berisi informasi mengenai data TKI berupa identitas dari TKI yang akan diberangkatkan. Pada halaman ini karyawan juga bisa menambahkan data TKI seperti yang ditunjukkan pada Gambar 5 dan melakukan pencarian berdasarkan nama TKI. Halaman data TKI terdapat pada Gambar 6.

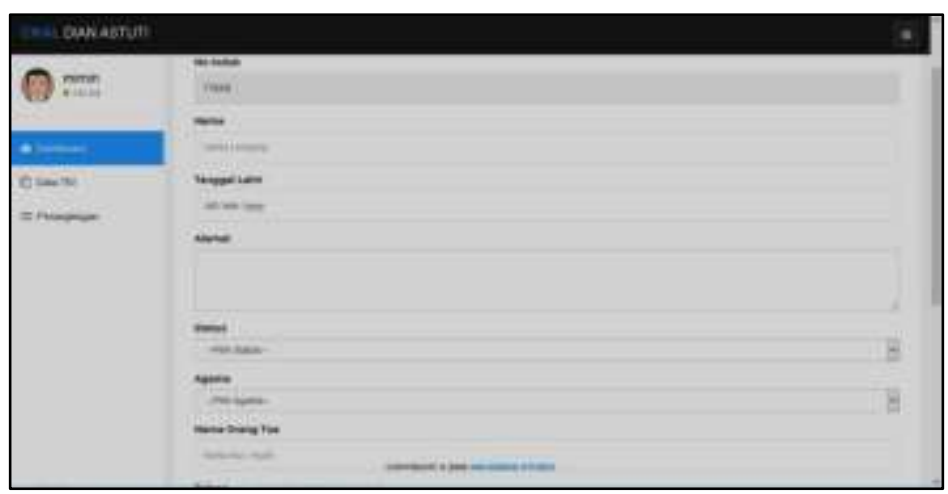

Gambar 5. Halaman masukan data TKI

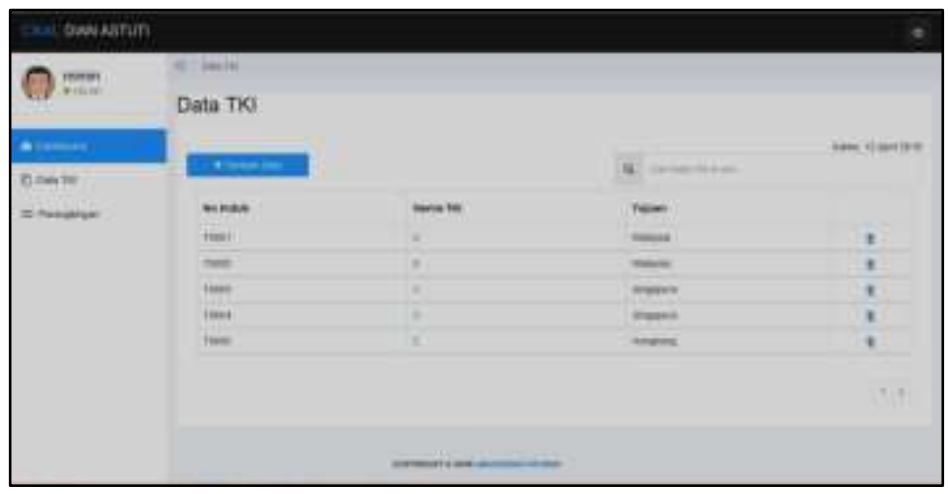

Gambar 6. Halaman data TKI

\section{d. Halaman Perangkingan}

Halaman perangkingan adalah halaman yang digunakan karyawan untuk melihat hasil perangkingan sesuai data yang telah dimasukkan pada halaman data TKI. Hasil dari perangkingan ini ditampilkan sesuai dengan gelombang yang ingin ditampilkan oleh karyawan. Di sini, hasil perangkingan telah terurutkan berdasarkan nilai tertinggi yang ditampilkan dalam bentuk tabel. Data TKI yang memiliki nilai di atas 0,60 direkomendasikan sebagai alternatif terbaik. Halaman perangkingan ini dapat dilihat pada Gambar 7. 


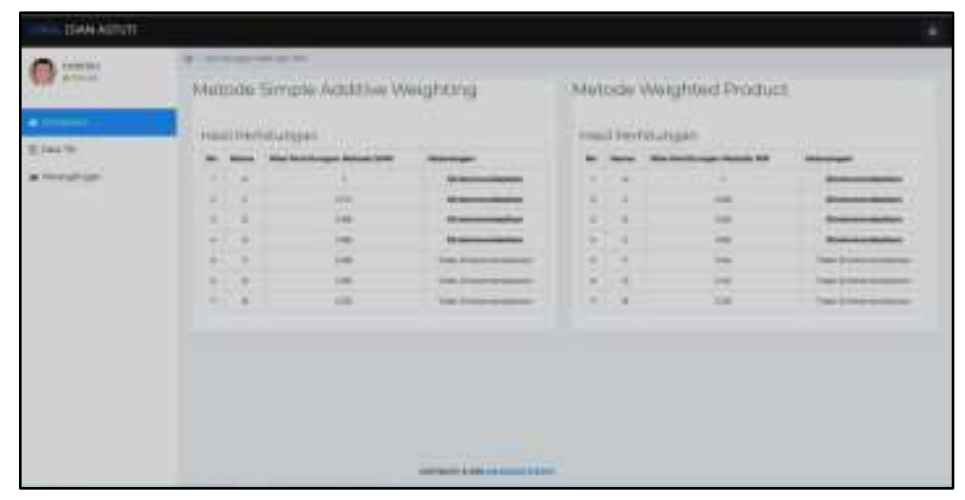

Gambar 7. Halaman perangkingan

Dalam penentuan kelayakan TKI ke luar negeri menggunakan data simulasi. Data tersebut kemudian diproses menggunakan metode Simple Additive Weighting (SAW) untuk mendapatkan rekomendasi kelayakan TKI. Berikut adalah langkah-langkah perhitungan metode Simple Additive Weighting (SAW) dan Weighted Product (WP) secara manual untuk penentuan kelayakan TKI ke luar negeri.

\section{Metode Simple Additive Weighting (SAW)}

- Membuat matrik awal

Matrik awal dibuat dari nilai-nilai yang telah dimasukkan dari setiap alternatif yang ditunjukkan pada Gambar 5. Berikut contoh kasus nilai kriteria pada setiap alternatif yang sudah dimasukkan seperti pada Gambar 6 yang ditunjukkan pada Tabel 5.

Tabel 5. Nilai Masukan Dari Setiap Alternatif Pada Setiap Kriteria

\begin{tabular}{ccccc}
\hline \multirow{2}{*}{ Alternatif } & \multicolumn{4}{c}{ Kriteria } \\
\cline { 2 - 5 } & Pengalaman kerja & Kesehatan & Usia & Pendidikan \\
\hline A & 5 & 3 & 5 & 5 \\
B & 1 & 1 & 3 & 1 \\
C & 5 & 2 & 3 & 1 \\
D & 1 & 2 & 5 & 4 \\
E & 2 & 3 & 3 & 5 \\
F & 4 & 1 & 3 & 2 \\
G & 4 & 1 & 4 & 4 \\
\hline
\end{tabular}

Dari Tabel 5 diperoleh matrik keputusan (X) sebagai berikut:

$$
X=\left|\begin{array}{llll}
5 & 3 & 5 & 5 \\
1 & 1 & 3 & 1 \\
5 & 2 & 3 & 1 \\
1 & 2 & 5 & 4 \\
2 & 3 & 3 & 5 \\
4 & 1 & 3 & 2 \\
4 & 1 & 4 & 4
\end{array}\right|
$$

- Membuat matrik ternormalisasi

Matrik keputusan $(\mathrm{X})$ dibuat dengan cara menghitung nilai rating kriteria dan diperoleh matrik ternormalisasi $(\mathrm{R})$ dengan pengalaman kerja, kesehatan, usia dan pendidikan sebagai benefit. Nilai R yang diperoleh seperti berikut: 


$$
R=\left[\begin{array}{cccc}
1 & 1 & 1 & 1 \\
0,2 & 0,33 & 0,6 & 0,2 \\
1 & 0,67 & 0,6 & 0,2 \\
0,2 & 0,67 & 1 & 0,8 \\
0,4 & 1 & 0,6 & 1 \\
0,8 & 0,33 & 0,6 & 0,4 \\
0,8 & 0,33 & 0,8 & 0,8
\end{array}\right]
$$

- Melakukan proses perangkingan

Proses perangkingan ini menggunakan bobot (W) yang telah ditentukan sesuai dengan tingkat kepentingan dari setiap kriteria sebagai berikut: nilai pengalaman kerja $=40 \%$, kesehatan $=30 \%$, usia $=20 \%$, dan pendidikan terakhir $=10 \%$. Berikut adalah perhitungan lengkapnya:

$$
W=[40 \% ; 30 \% ; \quad 20 \% ; \quad 10 \%]
$$

$\mathrm{A}=40 \%(1)+30 \%(1)+20 \%(1)+10 \%(1)=1$

$\mathrm{B}=40 \%(0,2)+30 \%(0,33)+20 \%(0,6)+10 \%(0,2)=0,32$

$\mathrm{C}=40 \%(1)+30 \%(0,67)+20 \%(0,6)+10 \%(0,2)=0,74$

$\mathrm{D}=40 \%(0,2)+30 \%(0,67)+20 \%(1)+10 \%(0,8)=0,56$

$\mathrm{E}=40 \%(0,4)+30 \%(1)+20 \%(0,6)+10 \%(1)=0,68$

$\mathrm{F}=40 \%(0,8)+30 \%(0,33)+20 \%(0,6)+10 \%(0,4)=0,58$

$\mathrm{G}=40 \%(0,8)+30 \%(0,33)+20 \%(0,8)+10 \%(0,8)=0,66$

\section{Metode Weighted Product (WP)}

- Membuat tabel matrik

Tabel matriks digunakan untuk melakukan proses perhitungan seperti yang dilakukan pada metode SAW pada Tabel 5.

- Melakukan perbaikan bobot

Perbaikan bobot terlebih dahulu dilakukan dengan cara sebagai berikut: bobot awal $\mathrm{w}=(40 \%, 30 \%, 20 \%, 10 \%)$ diperbaiki dengan menggunakan rumus $W_{j}=$ $\frac{W_{j}}{\Sigma W_{j}}$ sehingga total $=1$ dan diperoleh nilai seperti berikut:

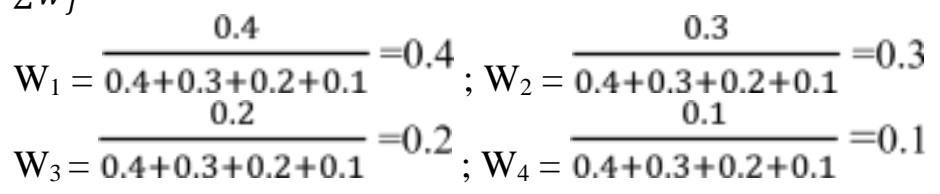

- Melakukan perhitungan vektor S

Vektor S dihitung berdasarkan persamaan (6) dan menghasilkan perhitungan sebagai berikut:

$$
\begin{aligned}
& \text { S1 }=\left(5^{0.4}\right) *\left(3^{0.3}\right) *\left(5^{0.2}\right) *\left(5^{0.1}\right)=4.289586 \\
& \text { S2 }=\left(1^{0.4}\right) *\left(1^{0.3}\right) *\left(3^{0.2}\right) *\left(1^{0.1}\right)=1.245731 \\
& \text { S3 }=\left(5^{0.4}\right) *\left(2^{0.3}\right) *\left(3^{0.2}\right) *\left(1^{0.1}\right)=2.919586 \\
& \text { S4 }=\left(1^{0.4}\right) *\left(5^{0.3}\right) *\left(2^{0.2}\right) *\left(4^{0.1}\right)=1.951232 \\
& \text { S5 }=\left(2^{0.4}\right) *\left(3^{0.3}\right) *\left(3^{0.2}\right) *\left(5^{0.1}\right)=2.684538 \\
& \text { S6 }=\left(4^{0.4}\right) *\left(1^{0.3}\right) *\left(3^{0.2}\right) *\left(2^{0.1}\right)=2.324616 \\
& \text { S7 }=\left(4^{0.4}\right) *\left(1^{0.3}\right) *\left(4^{0.2}\right) *\left(4^{0.1}\right)=2.639016
\end{aligned}
$$

- Menghitung nilai vektor V

Nilai vector $\mathrm{V}$ yang digunakan dalam perangkingan dihitung berdasarkan persamaan (3) dan menghasilkan nilai berikut. 


$$
\begin{aligned}
& \mathrm{V}_{1}=\frac{4.289586}{18.05431}=0.24 \\
& \mathrm{~V}_{2}-\frac{1.245731}{18.05431}-0.07 \\
& \mathrm{~V}_{3}^{\prime}-\frac{2.919586}{18.05431}-0.16 \\
& \mathrm{~V}_{4}=\frac{1.951232}{18.05431}=0.11 \\
& \mathrm{~V}_{5}-\frac{2.684538}{18.05431}-0.15 \\
& \mathrm{~V}_{6}=\frac{2.324616}{18.05431}=0.13 \\
& \mathrm{~V}_{7}=\frac{2.639016}{18.05431}=0.15
\end{aligned}
$$

Dari hasil perhitungan menggunakan metode WP dilakukan perangkingan seperti ditunjukkan pada Tabel 6.

Tabel 6. Hasil Perangkingan Metode WP

\begin{tabular}{ccc}
\hline Alternatif & Nilai V & Rangking \\
\hline A & 0.24 & 1 \\
C & 0.16 & 2 \\
E & 0.15 & 3 \\
G & 0.15 & 4 \\
F & 0.13 & 5 \\
D & 0.11 & 6 \\
B & 0.07 & 7 \\
\hline
\end{tabular}

- Melakukan normalisasi

Setelah memperoleh hasil nilai $\mathrm{V}$ pada perhitungan menggunakan metode WP, diperlukan normalisasi untuk mengetahui rekomendasi TKI yang dinyatakan layak sesuai dengan nilai minimum yang telah ditentukan yaitu sebesar 0.60 . Hasil V yang digunakan untuk melakukan normalisasi adalah nilai $\mathrm{V}$ tertinggi yang ada untuk menyetarakan nilai dengan metode Simple Additive Weighting (SAW) sehingga nilainya setara, dan dihitung berdasarkan persamaan 9.

$$
\begin{aligned}
& \quad \text { Normalisai }=\frac{V}{M a x V} \\
& \text { Normalisasi } \mathrm{V}_{1}=\frac{0.24}{0.24}=1 \\
& \text { Normalisasi } \mathrm{V}_{2}=\frac{0.07}{0.24}=0.29 \\
& \text { Normalisasi } \mathrm{V}_{3}=\frac{0.16}{0.24}=0.68 \\
& \text { Normalisasi } \mathrm{V}_{4}=\frac{0.11}{0.24}=0.45 \\
& \text { Normalisasi } \mathrm{V}_{5}=\frac{0.15}{0.24}=0.63 \\
& \text { Normalisasi } \mathrm{V}_{6}=\frac{0.13}{0.24}=0.54 \\
& \text { Normalisasi } \mathrm{V}_{7}=\frac{0.15}{0.24}-0.62
\end{aligned}
$$

Alternatif yang direkomendasikkan dari hasil perhitungan tersebut ditunjukkan pada Tabel 7. 
Tabel 7. Hasil Perangkingan Metode SAW dan WP

\begin{tabular}{cccc}
\hline \multicolumn{2}{c}{ SAW } & \multicolumn{2}{c}{ WP } \\
\hline Alternatif & Nilai & Alternatif & Nilai \\
\hline A & 1 & A & 1 \\
C & 0,74 & C & 0,68 \\
E & 0,68 & E & 0,63 \\
G & 0,66 & G & 0,62 \\
\hline
\end{tabular}

Berdasarkan hasil pada Tabel 7 menunjukkan bahwa antara metode SAW dan metode WP keduanya menghasilkan urutan ranking alternative yang sama, meskipun memiliki nilai yang sedikit berbeda. Hal ini disebabkan karena adanya perbedaan persamaan yang digunakan dan dipengaruhi pula oleh adanya pembualatan angka.

\section{KESIMPULAN}

Berdasarkan penelitian yang dilakukan telah dikembangkan sebuah sistem pendukung keputusan online kelayakan TKI ke luar negeri menggunakan metode Simple Additive Weighting (SAW) dan Weighted Product (WP) pada PPTKIS CIKAL DIAN ASTUTI. Kesimpulan dari hasil pengujiam kedua metode tersebut diperoleh informasi bahwa rekomendasi yang dihasilkan adalah sama, sehingga kedua metode ini bisa dipertimbangkan untuk digunakan dalam pemilihan kelayakan TKI yang akan diberangkatkan. Sebagai saran tindak lanjut dari penelitian ini adalah sistem ini dapat dikembangkan dengan berbasis android dan bisa dicoba dengan menggunakan metode SPK lainnya seperti TOPSIS sehingga dapat diketahui metode terbaik dalam penyelesaian permasalahan tersebut.

\section{DAFTAR PUSTAKA}

Adlhiyah, L. dan Mustafidah, H., (2016), Sistem Pendukung Keputusan Pemilihan Lensa Kontak (Softlens) Menggunakan Metode Simple Additive Weighting (SAW), JUITA, ISSN: 2086-9398, Vol. IV, Nomor 2, November 2016, hal 105-115.

Anto, A.G., Mustafidah, H., dan Suyadi, A., (2015), Sistem Pendukung Keputusan Penilaian Kinerja Karyawan Menggukan Metode SAW (Simple Additive Weighting) di Universitas Muhammadiyah Purwokerto, JUITA, ISSN: 2086-9398, Vol. III, Nomor 4, November 2015, hal 193-200.

Ariani, A., Abdillah, A,L, dan Syakti, F., (2013). Sistem Pendukung Keputusan Kelayakan TKI ke Luar Negeri Menggunakan FMADM. Jurnal Sistem Informasi. Volume 4, Nomor 5, September 2013, hal 336-343.

Mustafidah, H., dan Hadyan, H.N., (2017), Sistem Pendukung Keputusan Penentuan Mahasiswa Berprestasi di Universitas Muhammadiyah Purwokerto Menggunakan Metode Weighted Product (WP), JUITA, ISSN: 2086-9398, Vol. V, Nomor 1, Mei 2017, hal 51-61.

Nofriansyah, D. (2014). Konsep Data Mining Vs Sistem Pendukung Keputusan. Yogyakarta: DEEPUBLISH.

Yoni, D.C., dan Mustafidah, H., (2016), Penerapan Metode WP (Weighted Product) Untuk Pemilihan Mahasiswa Lulusan Terbaik di Fakultas Teknik Universitas Muhammadiyah Purwokerto, JUITA, ISSN: 2086-9398, Vol. IV, Nomor 1, Mei 2016, hal 22-27. 